\title{
Evaluation of Some Sugarbeet Varieties for Their Susceptibility to Root- knot Nematode, Meloidogyne incognita, According to Modified Host Parasite Index (MHPI) Scale
}

\author{
Maareg, M. F. ; A. Y. El- Gindi ${ }^{* *}$; Mona E. El- Shalaby and Abeer, S. Yassin \\ * Department of Plant Protection, Sugar Crops, Research Institute, Agriculture Research Center, Giza, Egypt. \\ ** Department of Agriculture Zoology and Nematology, Faculty of Agriculture, Cairo University, Giza, Egypt.
}

\begin{abstract}
The host suitability of the ten sugarbeet varieties of monogerm (i.e., Estaban, Francescan, Sander, Sible and Univers) and multigerm (i.e., Heba, Lilly, Mammut, Mirados and Oscarpoly) to $M$. incognita infection was conducted under greenhouses condition. Results revealed that all yield characters (root, top and sugar yields) and quality characters, (sucrose, total soluble solids and purity \%) of such screened sugarbeet variety were obviously diminished by $M$. incognita infection to great extort. The degree of susceptibility/ resistance of these sugarbeet varieties evaluated according to modified host parasite index (MHPI) scale which was used as a new and suitable scale (special technique) to assess host (sugarbeet plant) reaction. The MHPI is calculated by dividing a gross average of reduction percentages in all yield and quality characters by the susceptibility rate. It could be ranked as standardization of host suitability technique and reporting of resistance of sugarbeet to root- knot nematodes. On this basis, the screened sugarbeet varieties are categorized into three groups, two varieties are as tolerant host (Heba and Sible), four as low susceptible (Estaban, Lilly, Mirador and Sandor) and four as moderately susceptible (Francescan, Mammut, Oscarpoly and Univers) against root- knot nematode, $M$. incognita. So, they could be Heba (as multigerm) and Sible (as monogerm) varieties recommended as excellent commercial varieties in Egypt, and could be introduced in integrated pest management (IPM) for controlling root-knot nematodes.
\end{abstract}

Key words: damage index, host parasite, Meloidogyne incognita, root- knot nematodes, resistance, sugarbeet varieties, susceptibility and susceptibility rate.

\section{Introduction}

Sugarbeet plant is attacked by certain pathogens and weeds in all sugarbeet growing in Egypt which affected its growth, yield and quality. In this context, the root- knot nematode, Meloidogyne incognita Kofoid and White (Chitwood), is considered the most significant yield and quality limiting pathogen (Abd El- Massih, 
1985; Maareg et al., 1988a; Ismail et al., 1996; Maareg and Hassanein, 1999; Gohar, 2003; Gohar and Maareg, 2005 and Maareg et al., 2005). Yield losses of sugarbeet production caused by $M$. incognita as much as 50.8 and $68.4 \%$ in roots yield and sugar yield, respectively, have been observed in heavily- infested sites of certain sugarbeet fields in the West Nubariya district (Gohar and Maareg, 2005). Control strategies for $M$. incognita, root- knot nematode in Egypt have primarily relied on the use of chemical nematicides. Crop rotation and cultural practices method have also been employed. No resistant varieties have yet been imported.

Many investigators evaluated some sugarbeet varieties against root- knot nematodes, Meloidogyne spp., Maareg et al., (1988b and 1998) classified some sugarbeet varieties into highly susceptible, susceptible and moderately resistant against the root- knot nematode, $M$. javanica and $M$. incognita based on numbers of galls or eggmasses. However, Maareg et al., (2005) evaluated twenty one sugarbeet varieties infected by $M$. incognita according to root damage index (DI) which was calculated as an average of gall index (GI), gall size (GS) and gall area (GA) according to Sharma et al., (1994). Also, Abd- El- Khair et al., (2013) evaluated five sugarbeet varieties exhibited various degrees of susceptibility to $M$. incognita depending on their damage index. El- Nagdi et al., (2004) and Youssef et al., (2016) screened certain sugarbeet varieties for their susceptibility/ resistance against root- knot nematode, $M$. incognita according to their damage index (DI) and percentage host vigor which were combined together to evaluation of the tested varieties. Gohar et al., (2013) evaluated some sugarbeet varieties for their susceptibility/ resistance against $M$. incognita based on combination between gall index and reproduction factor $\left(\mathrm{P}_{\mathrm{f}} / \mathrm{P}_{\mathrm{i}}\right)$ according to Canto- Saenz and Brodie (1986). The host parasite index (HPI) as a susceptibility/ tolerance value was used to evaluation of imported sugarbeet varieties for root- knot nematodes, Meloidogyne spp. In this scale, Ismail et al., (1996) used the reduction in characters of plant growth (dry weight of root and leaves per plant and diameter of root) and quality in tested plants for comparing the effects of root- knot nematodes. However, Maareg et al., (2009) used the reduction which occurs in characters of sugarbeet yield (roots yield, top yield and sugar yield) and quality to be a better characters for comparing pathogenic effects of nematodes. The modified host parasite index (MHPI) scale according to Maareg et al., (2009) is more suitable because of generally high correlation between these characters and crop damage. This reduction in roots and sugar yields as well as sucrose\% are very important as its affects the suitability of sugarbeet varieties for both farmers and sugar industry. The main aim of this research is to evaluating the sensitively of new imported sugarbeet varieties against root- knot nematode, $M$. incognita using MHPI scale according to Maareg et al., (2009).

\section{Materials and Methods}

The ten imported sugarbeet varieties used in this study were obtained from 
Sugar Crops Research Institute (SCRI), Agriculture Research Center (ARC), Egypt. Seed type and origin of sugarbeet varieties used tabulated in Table (1). Seeds of these varieties were planted separately in $30 \mathrm{~cm}$ diameter earthen pots filled with stem sterilized sandy loam soil (the soil was heat- sterilized at $60^{\circ} \mathrm{C}$ for 45 minutes) in the first week of October, 2015. At four leaves stage, seedlings were thinned to one vigorous plant per pot. For each sugarbeet variety, ten pots with similar in their growth were selected, five of those were inoculated with 2000 newly hatched action second stage juveniles $\left(\mathrm{J}_{2 \mathrm{~s}}\right)$ of $M$. incognita into four holes 3 - 5 depth around the sugarbeet root which were immediately covered and mixed with soil. Inoculum of $M$. incognita was prepared following the methods of Hussey and Barker (1973) by extracting nematode eggs from previously infected tomato grown on pure culture using a $1.5 \% \mathrm{NaOCl}$ solution. The other five pots were kept without inoculation as control. All pots were arranged in a completely randomized block design in a glasshouse at $20 \pm 5^{\circ} \mathrm{C}$ and $65 \pm 5 \mathrm{RH}$. All pots were managed throughout the growing season by standard agricultural practices and were irrigated as needed. Six months after nematode juveniles inoculation, the soil of each pot was well irrigated before removing the plant. Roots were washed in a gentle flow top water. Fresh weights of leaves and root plant ${ }^{-1}$ were recorded. Infected plant root were examined for determine the number of galls.

Table (1). Seed type and origin of sugarbeet varieties used in the study.

\begin{tabular}{lll}
\hline \multicolumn{1}{c}{ Variety } & Seed type & Origin \\
\hline 1. Estaban & Monogerm $(\mathrm{z})$ & Germany \\
\hline 2. Francesca & Monogerm $(\mathrm{Nz})$ & Netherland \\
\hline 3. Heba & Multigerm & Denmark \\
\hline 4. Lilly & Multigerm $(\mathrm{Nz})$ & Denmark \\
\hline 5. Mammut & Multigerm $(\mathrm{z})$ & Denmark \\
\hline 6. Mirador & Multigerm $(\mathrm{Nz})$ & Denmark \\
\hline 7. Oscarpoly & Multigerm $(\mathrm{N})$ & Denmark \\
\hline 8. Sandor & Monogerm $(\mathrm{Nz})$ & Germany \\
\hline 9. Sibel & Monogerm $(\mathrm{Nz})$ & Belgium \\
\hline 10. Univers & Monogerm $(\mathrm{En})$ & Netherland \\
\hline
\end{tabular}

Root gall index (GI), gall size (GS), gall area (GA) and nematode damage index (DI) were estimated according to Sharma et al., (1994). The number of developmental stages in root system was determined after staining by lactic acidfuchsin (Byrd et al., 1983) and recorded. Number of $M$. incognita juveniles in pot 
soil was also determined by extracting through sieve and modified Baermann- pan technique (Goodey, 1957) and recorded. The technological characters on the basis of total soluble solids (T.S.S) percentage was measured in the fresh roots by hand refractometer, sucrose percentage was determined according to Le Docte as described by Mc Ginnis (1982) and purity percentage was calculated as a ratio between sucrose $\%$ and T.S.S.\%. Sugar yield plant- ${ }^{1}$ was calculated by multiplied sucrose $\% \times$ root weight.

The susceptibility or tolerance degree of screened sugarbeet varieties was determined by modified host parasite index (MHPI) scale according to Maareg et al., (2009) as a new susceptibility/ resistance value which states the amount of reduction in yield and technological characters caused by nematode infection accorded to following formula:

$\mathrm{MHPI}=2\left[\mathrm{R}_{\mathrm{yi}}+\mathrm{R}_{\text {tech }}\right] \div\left(\mathrm{SR} \times \mathrm{P}_{\mathrm{yi}+\text { tech }}\right)$

Where:

$$
\begin{aligned}
\mathrm{R}_{\mathrm{yi}} & =\text { Total reduction in yield characters } \\
\mathrm{R}_{\text {tech }} & =\text { Total reduction in technological characters } \\
\mathrm{P}_{\text {yittech }} & =\text { Number of yield and technological characters } \\
\mathrm{SR} & =\text { Susceptibility rate } \\
& =(\mathrm{RF}+\mathrm{DI}) / 2
\end{aligned}
$$

Where:

$\mathrm{RF}=$ Reproduction factor $=$ final population $\left(\mathrm{P}_{\mathrm{f}}\right) /$ initial population $(\mathrm{Pi})$ according to Oostenbrik (1966)

$D I=(G I+G S+G A) / 3$ according to Sharma et al., (1994).

Sugarbeet varieties with MHPI $\leq 4.0$ is considered as tolerant $(\mathrm{T}), 4.1-6.0$ as low susceptible (LS), $6.1-8$ as moderately susceptible and $\geq 8.1$ as highly susceptible (HS). Least significant differences (LSD) and a paired T- test at 0.05 and 0.01 were performed for all data.

\section{Results}

The host suitability of the ten sugarbeet plant varieties of five monogerm i.e., Estaban, Francescan, Sandor, Sible and Univers, and five multigerm i.e., Heba, Lilly, Mammut, Mirador and Oscarpoly to M. incognita root- knot nematode infection was conducted under greenhouse condition $\left(20 \pm 5^{\circ} \mathrm{C}\right.$ and $\left.65 \pm 5 \mathrm{RH}\right)$. Results revealed that all yield and quality characters of such screened sugarbeet plant varieties were obviously diminished by $M$. incognita infection to great extent as shown in Tables 2 and 3. 
Significant differences $(P=0.05$ and 0.01 ) are found between infected and non infected plants within screened sugarbeet varieties in yield characters i.e., root, top and sugar yields plant ${ }^{-1}$. All the evaluated sugarbeet varieties had significantly decreased in all yield characters except, for Univers variety only in top yield plant ${ }^{-1}$ and Heba variety in both top and sugar yields which were not significantly decreased. The percentage reduction in root yield ranged from 7.0 in Heba variety

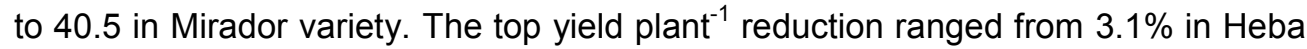
variety to $49.8 \%$ in Mirador variety. In sugar yield plant $^{-1}$, the ranged reduction varied from $15.9 \%$ in Heba variety to $48.5 \%$ in Mirador variety, and in total reduction of yield characters from $26.0 \%$ in Heba variety to $138.0 \%$ in Mirador variety, also, the Sandor and Francescan varieties recorded 108.1 and $89.3 \%$ in total reduction\%, respectively. Generally, the Mirador variety attained the highest reduction in root, top and sugar yields as well as total yields, but Heba variety had the lowest ones (Table, 2).

Also, significant differences $(P=0.05$ and 0.01$)$ are found between infected and non- infected plants within tested sugarbeet varieties in quality characters (sucrose\%, total soluble solids\% (T.S.S\%) and purity\%). All the tested sugarbeet varieties had significantly decreased in all quality characters, except, for Sandor, Sible and Heba varieties which were not significantly decreased only in T.S.S\%. The ranged reduction in sucrose $\%$ was $9.9 \%$ in Heba variety to $31.2 \%$ in both Francescan and Oscarpoly varieties, and in T.S.S\% from 2.8 in Mirador variety to $20.7 \%$ in Francescan variety. Reduction in purity\% ranged from $3.5 \%$ in Lilly variety to $16.7 \%$ in Oscarpoly variety. The total reduction of quality characters ranged from $20.0 \%$ in Heba variety to 65.2 and $65.1 \%$ in Oscarpoly and Francescan varieties, respectively, (Table, 3).

Significant differences were found in $\mathrm{J}_{2 \mathrm{~s}}$ in soil, developmental stages in root system, total numbers $\left(P_{f}\right)$, reproduction factors $(R F), G I, G S, G A, D I$ and SR. The $\mathrm{J}_{2 \mathrm{~s}}$ in soil range was 7903- 14732 with Heba variety having the lowest and Sandor, Francescan and Mirador the highest values. The different stages in root system values ranged from 1594 in Heba variety to 8000 in Estaban variety, and in total nematode $\left(P_{f}\right)$ values from 9497 in Heba variety to 21485 in Mirador variety. The values of RF ranged generally, from 4.7 for Heba variety to 10.7 for Mirador variety. Eventually, the varieties, Mirador, Estaban and Lilly attained the highest RF, and Heba, Sible and Mammut varieties had the lowest RF values. The GI value ranged from 6.0- 9.0 with Heba variety having the lowest and Francescan and Mirador varieties the highest values. The GS range was 5.5- 90, with Heba variety having the lowest and Sible and Mirador varieties the highest values. The GA values ranged from 5.0 in Univars, Heba and Mammut varieties to 9.0 in Francescan and Mirador varieties. The DI range was from 5.5 to 8.9 with Heba variety having the lowest and Mirador and Francescan the highest values. The SR values ranged from 5.1 in Heba variety to 9.8 in Mirador variety. Eventually, the variety, Heba attained the lowest $P_{f}, R F, G I, D I$ and $S R$ values and Mirador variety had the highest ones (Table, 4). 
Table (2): Root, top and sugar yields of the screened sugarbeet varieties as influenced by the infection of root- knot nematode, Meloidogyne incognita.

\begin{tabular}{|c|c|c|c|c|c|c|c|c|c|c|}
\hline \multirow{2}{*}{$\begin{array}{c}\text { Sugarbeet } \\
\text { varieties }\end{array}$} & \multicolumn{3}{|c|}{ Root yield plant $^{-1}(\mathrm{~g})$} & \multicolumn{3}{|c|}{ Top yield plant $^{-1}(\mathrm{~g})$} & \multicolumn{3}{|c|}{ Sugar yield plant $^{-1}(\mathrm{~g})$} & \multirow{2}{*}{$\begin{array}{l}\text { Total reduction of } \\
\text { yield characters }\end{array}$} \\
\hline & Control & Infected & $\mathbf{R} \%$ & Control & Infected & $\mathbf{R} \%$ & Control & Infected & $\mathbf{R} \%$ & \\
\hline \multicolumn{11}{|l|}{ Monogerm } \\
\hline Estaban & 835.3 & $689.8^{* *}$ & 17.4 & 333.7 & $262.1^{*}$ & 21.5 & 125.9 & $81.5^{\star \star}$ & 35.3 & 74.2 \\
\hline Francescan & 761.2 & $622.6^{\star *}$ & 18.2 & 312.8 & $227.3^{*}$ & 27.3 & 129.6 & $72.8^{* *}$ & 43.8 & 89.3 \\
\hline Sandor & 772.5 & $550.0^{* *}$ & 28.8 & 320.0 & $195.0^{* *}$ & 39.1 & 127.6 & $76.3^{* *}$ & 40.2 & 108.1 \\
\hline Sible & 865.6 & $730.7^{*}$ & 15.6 & 297.9 & 262.0 & 12.1 & 153.0 & $113.7^{*}$ & 25.7 & 53.4 \\
\hline Univers & 689.2 & $564.4^{* *}$ & 18.1 & 296.5 & 259.6 & 12.4 & 116.1 & $68.2^{* \star}$ & 41.3 & 71.8 \\
\hline \multicolumn{11}{|l|}{ Multygerm } \\
\hline Heba & 637.8 & $592.9^{*}$ & 7.0 & 314.4 & 304.8 & 3.1 & 108.8 & 91.5 & 15.9 & 26.0 \\
\hline Lilly & 788.1 & $652.2^{* *}$ & 17.2 & 372.9 & $304.8^{*}$ & 18.3 & 158.1 & $104.2^{*}$ & 34.1 & 69.6 \\
\hline Mammut & 865.7 & $642.5^{* *}$ & 25.8 & 322.5 & $212.6^{* *}$ & 34.1 & 153.1 & $92.3^{* *}$ & 39.7 & 99.6 \\
\hline Mirador & 747.8 & $445.0^{* *}$ & 40.5 & 340.3 & $170.7^{* *}$ & 49.8 & 136.0 & $70.0^{* *}$ & 48.5 & 138.8 \\
\hline Oscarpoly & 798.3 & $650.0^{* *}$ & 18.6 & 347.8 & $257.3^{* *}$ & 26.0 & 148.2 & $83.3^{* \star}$ & 43.8 & 88.4 \\
\hline
\end{tabular}

*and ** significant at 0.05 and 0.01 probability levels, respectively.

$\mathrm{R} \%=$ Reduction $\%$ 
Table (3): Sucrose, total soluble solids (T.S.S) and purity percentages of the screened sugarbeet varieties as influenced by the infection of root- knot nematode, Meloidogyne incognita.

\begin{tabular}{|c|c|c|c|c|c|c|c|c|c|c|}
\hline \multirow{2}{*}{$\begin{array}{l}\text { Sugarbeet } \\
\text { Varieties }\end{array}$} & \multicolumn{3}{|c|}{ Sucrose $\%$} & \multicolumn{3}{|c|}{ T.S.S\% } & \multicolumn{3}{|c|}{ Purity\% } & \multirow{2}{*}{$\begin{array}{l}\text { Total reduction of } \\
\text { quality characters }\end{array}$} \\
\hline & Control & Infected & $\mathbf{R} \%$ & Control & Infected & $\mathbf{R} \%$ & Control & Infected & R\% & \\
\hline \multicolumn{11}{|l|}{ Monogerm } \\
\hline Estaban & 15.1 & $11.8^{* *}$ & 21.9 & 20.3 & $17.3^{\star *}$ & 14.8 & 74.4 & $68.2^{*}$ & 8.3 & 45.0 \\
\hline Francesca & 17.0 & $11.7^{* *}$ & 31.2 & 22.2 & $17.6^{* \star}$ & 20.7 & 76.6 & $66.5^{\star *}$ & 13.2 & 65.1 \\
\hline Sandor & 16.5 & $13.9^{* \star}$ & 15.8 & 20.8 & 19.2 & 7.7 & 79.3 & $72.4^{\star \star}$ & 8.7 & 32.2 \\
\hline Sible & 17.5 & $15.6^{* *}$ & 10.9 & 20.2 & 19.3 & 4.5 & 86.6 & $80.8^{*}$ & 6.7 & 22.1 \\
\hline Univers & 16.8 & $12.1^{* *}$ & 28.0 & 20.1 & $16.6^{\star *}$ & 17.4 & 83.6 & $72.9^{* *}$ & 12.8 & 58.2 \\
\hline \multicolumn{11}{|l|}{ Multygerm } \\
\hline Heba & 17.1 & $15.4^{*}$ & 9.9 & 20.3 & 19.4 & 4.4 & 84.2 & $79.4^{*}$ & 5.7 & 20.0 \\
\hline Lilly & 20.1 & $16.0^{* \star}$ & 20.4 & 22.8 & $18.8^{*}$ & 17.5 & 88.2 & $85.0^{*}$ & 3.5 & 41.4 \\
\hline Mammut & 17.7 & $14.4^{* *}$ & 18.6 & 20.7 & $18.4^{*}$ & 11.1 & 85.6 & $78.3^{* *}$ & 8.2 & 37.9 \\
\hline Mirador & 18.2 & $15.7^{*}$ & 13.7 & 21.3 & $20.7^{*}$ & 2.8 & 85.4 & $75.8^{* *}$ & 11.2 & 27.7 \\
\hline Oscarpoly & 18.6 & $12.8^{* *}$ & 31.2 & 25.5 & $21.1^{* *}$ & 17.3 & 72.9 & $60.7^{* *}$ & 16.7 & 65.2 \\
\hline
\end{tabular}

${ }^{*}$ and ${ }^{* *}$ significant at 0.05 and 0.01 probability levels, respectively.

$\mathrm{R} \%=$ Reduction $\%$ 
Table (4): The population density, reproduction factor, root galling symptoms, damage index, susceptibility rate, modified host parasite index and host category of root- knot nematode, Meloidogyne incognita on the screened sugarbeet varieties.

\begin{tabular}{|c|c|c|c|c|c|c|c|c|c|c|c|}
\hline $\begin{array}{l}\text { Sugarbeet } \\
\text { varieties }\end{array}$ & 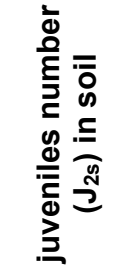 & 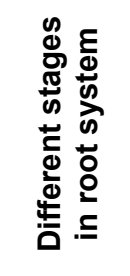 & 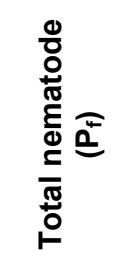 & 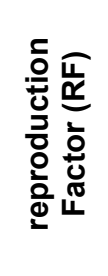 & 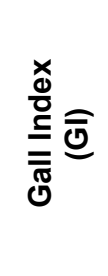 & 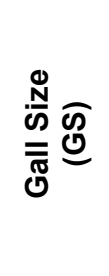 & 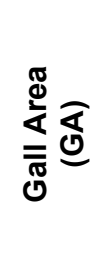 & 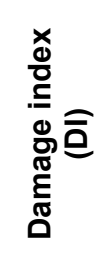 & 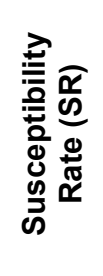 & 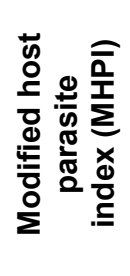 & 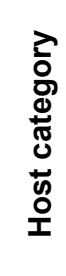 \\
\hline \multicolumn{12}{|l|}{ Monogerm } \\
\hline Estaban & $10249 d$ & $8000 a$ & $18249 b$ & $9.1 \mathrm{~b}$ & $7.0 \mathrm{~d}$ & $6.0 \mathrm{~d}$ & $7.7 \mathrm{bc}$ & $6.9 c$ & $8.0 \mathrm{~b}$ & 5.0 & LS \\
\hline Francescan & $13475 b$ & $2997 e$ & $16472 \mathrm{c}$ & $8.2 \mathrm{c}$ & $9.0 \mathrm{~b}$ & $8.3 b$ & $9.0 \mathrm{a}$ & $8.7 a$ & $8.5 b$ & 6.1 & MS \\
\hline Sandor & $14732 a$ & $1929 e$ & 16661c & $8.3 c$ & $7.7 \mathrm{~b}$ & $8.0 \mathrm{~b}$ & $7.3 c$ & $7.7 \mathrm{~b}$ & $8.0 \mathrm{~b}$ & 5.8 & LS \\
\hline Sible & 9362ef & $3962 d$ & $13324 \mathrm{e}$ & $6.7 d$ & $8.7 a$ & $9.0 \mathrm{a}$ & $6.3 d$ & $8.0 \mathrm{~b}$ & $7.4 \mathrm{c}$ & 3.4 & $\mathrm{~T}$ \\
\hline Univers & $9189 f$ & $5279 c$ & $14468 d$ & $7.2 \mathrm{~d}$ & $7.3 d$ & $6.1 d$ & $5.0 \mathrm{e}$ & $6.1 \mathrm{de}$ & $6.7 c$ & 6.5 & MS \\
\hline \multicolumn{12}{|l|}{ Multygerm } \\
\hline Heba & $7903 \mathrm{~g}$ & $1594 \mathrm{e}$ & $9497 f$ & $4.7 e$ & $6.0 \mathrm{e}$ & $5.5 e$ & $5.0 \mathrm{e}$ & $5.5 e$ & $5.1 \mathrm{f}$ & 3.0 & $\mathrm{~T}$ \\
\hline Lilly & 9787de & $7281 b$ & $17068 b$ & $8.5 c$ & $8.0 \mathrm{~cd}$ & $6.3 \mathrm{~cd}$ & $6.1 d$ & $6.8 \mathrm{~cd}$ & $7.6 \mathrm{bc}$ & 4.8 & LS \\
\hline Mammut & 9479de & $4122 \mathrm{~cd}$ & $13601 \mathrm{e}$ & $6.8 b$ & $7.8 \mathrm{~b}$ & $6.5 c$ & $5.0 \mathrm{e}$ & $6.4 d$ & $6.6 \mathrm{e}$ & 6.9 & MS \\
\hline Mirador & 13637b & 7848ab & $21485 a$ & $10.7 a$ & $9.0 a$ & $8.7 a$ & $9.0 a$ & $8.9 a$ & $9.8 a$ & 5.7 & LS \\
\hline Oscarpoly & $11151 \mathrm{c}$ & $5501 c$ & $16652 c$ & $8.3 c$ & $8.0 \mathrm{~b}$ & $8.0 \mathrm{~b}$ & $8.2 b$ & $8.1 \mathrm{~b}$ & $8.2 b$ & 6.2 & MS \\
\hline
\end{tabular}

LS= Low susceptible

MS= Moderately susceptible

$\mathrm{T}=$ Tolerant 
The data cleared that the different sugarbeet varieties have a great variation in their susceptibility/ resistance to infection with $M$. incognita. Thus, could be classified according to MHPI scale (Maareg, 2009) into there significantly separated groups, two varieties, Heba and Sible are considered as tolerant, four varieties, Esteban, Lilly, Mirador and Sandor are considered as low susceptible and four varieties, Francescan, Mammut, Oscarpoly and Univers are considered as moderate susceptible.

\section{Discussion}

In this study, statistical differences $(P=0.05 \& 0.01)$ are found between infected and non- infected plants within varieties of sugarbeet in various yield and quality characters. Results revealed that the yield and quality characters of such screened sugarbeet plant varieties were obviously diminished by $M$. incognita infection to great extent. Also, the screened varieties which were infected with $M$. incognita showed significant differences in symptoms of root galling, damage index, final population, reproduction factor and susceptibility rate. These results are in accordance with those reported by Ismail et al., (1996) and Maareg et al., (2009).

Concerning categorization of imported sugarbeet varieties as affected by root- knot nematode, Meloidogyne spp. In Egypt, Maareg et al., (1988b and 1998) classified some sugarbeet varieties into different degrees of susceptible against $M$. incognita and M. javanica based galls and / or eggmasses numbers. Also, Maareg et al., (2005) and Abd- El- Khair et al., (2013) evaluated some sugarbeet varieties exhibited various degrees of susceptibility to $M$. incognita depending on their damage index. However, Gohar et al., (2013) assessed certain sugarbeet varieties against $M$. incognita based on combination between gall index and reproduction factor. In spite of the importance of the scales in expressing the differences in the degrees of nematode development, reproduction factor and damage index, the results indicated that these scales not take into consideration the evaluation of real damage occurring in plant growth, yield and quality characters of nematode infected sugarbeet plant.

On the other hand, El- Nagdi et al., (2004) and Yussef et al., (2016) evaluated some sugarbeet varieties for their susceptibility/ resistance against $M$. incognita according to percentage host vigor which was calculated as an average of percentages root and leaves weight potentials (total yield potential) and quality characters (where: $\%$ total yield potential $=($ total yield of each variety $/$ the highest total yield of given variety multiple by 100 ) and $\%$ host vigor $=$ an average of $\%$ total yield potential $+\%$ sucrose $+\%$ purity $+\%$ total soluble solids). In this scale, the resistance degree of a variety varies according to the group items in it. Ismail et al., (1996) assessed some sugarbeet according to host parasite index (HPI) which is express the amount of damage rather than nematode symptoms, in both plant growth (in dry weight of leaves and roots and in diameter of root) and quality 
characters caused by nematode infection. Also, these scales does not consider the real damage which accurse in roots, top and sugar yields and production characters in tested varieties. Hence, a new scale, modified host parasite index (MHPI) according to Maareg et al., (2009) is more suitable because of the generally high correlation between the reduction $\%$ in both total yield and quality characters and crop damage, which where record low economic value of farm production.

Also, using the reduction in roots and sugar yields as well as sucrose, T.S.S and purity percentages in this respect, are very important as its affects the suitability of sugarbeet varieties for both farmers and sugar companies.

In conclusion, the MHPI scale could be ranked as standardization of host suitability method and reporting of resistance of sugarbeet to root- knot nematodes.

\section{References}

Abd- El- Kheir, H.; A. I., Abd- El- Fattah and W. M. A., El- Nagdi (2013). Evaluation of five sugarbeet varieties for root- knot nematode and root- rot fungal infection. Arch. Phytopathol. Plant Port. 46: 2163- 2173.

Abd El- Massih, M.; S. El- Eraki and A. Y. El- Ginidi (1985). Plant parasite nematodes associated with sugarbeet in Egypt. Bull. Fac. Agric., Cairo Univ., 37: 477- 483.

Byrd, D. W.; T. Kirkaptrick and K., Barker (1983). An improved technique for clearing and staining plant tissue for detection of nematodes. J. Nematol., 15 (3): 142- 143.

Canto- Saenz, M. and B. B., Brodie (1986). Host efficiency potato to Meloidogyne incognita and damage threshold densities on potatoes. Nematropica, 16 (2): 109- 116. Halmithol, Abstr., 56 (2): 44.

El- Nagdi, W. M. A.; M. M. A. Youssef and Z. R. Mostafa (2004). Reaction of sugarbeet varieties to Meloidogyne incognita root- knot nematode based on quantitative and qualitative yield characteristics. Pak. J. Nematol., 22: 157162.

Gohar, I. M. A. (2003). The relationships between plant parasite nematodes of sugarbeet and other soil fauna. Ph. D. Thesis, Fac. Agric. Moshtohor Zagazig Univ., Egypt, 221 pp.

Gohar, I. M. A.; A. A., Abo. El- Ftooh; M. S. Saleh and M. Kh., El- Shnawy (2013). Tolerance effect of some sugarbeet varieties to root- knot nematode, Meloidogyne incognita and efficacy of nemacur (Fenamiphos) control under field conditions. Alex. Sci. Exch. 34 (1): 129- 139.

Gohar, I. M. A. and M. F., Maareg (2005). Relationship between crop losses and initial population densities of root- knot nematode, Meloidogyne incognita in soil of sugarbeet grown in West Nubariya district. J. Agric. Res., 83 (4): 1315- 1328. 
Goody, J. B. (1957). Laboratory methods for work with plant and soil nematodes. Tech. Bull. Minist. Agric., Fish. \& Food, No. 2 London. 47 pp.

Hussey, R. S. and K. R., Barker (1973). A comparison of methods collecting inocula of Meloidogyne spp. including a new technique. Plant Dis. Rep. 57: 1025- 1028.

Ismail, A. E.; H. Z. Aboul- Eid and S. Y. Besheit (1996). Effects of Meloidogyne incognita on growth response and technological characters of certain sugarbeet varieties. Int. J. Nematol., 6: 195- 202.

Maareg, M. F.; A. Y. El- Gindi; Mona, E. El- shalaby and Abeer, S. Yassin (2009). Evaluation of certain sugarbeet varieties for their productivity and susceptibility to root- knot nematode, Meloidogyne incognita. J. Agric. Sci. Mansoura, 34 (6): 6851- 6861.

Maareg, M. F. and M. A., Hassanein (1999). Survey and ecological studies on plant parasitic nematodes in West Nubariya. In. The effects of nematode on sugarbeet at Al- Bostan region. Project funded from National Council of sugar crops (NCSC). $51 \mathrm{pp}$.

Maareg, M. F.; M. A., Hassanein; A. I., Allam and B. A., Oteifa (1998). Susceptibility of twenty six sugarbeet varieties to root- knot nematodes, Meloidogyne spp., in the newly reclaimed sandy soils of Al- Bostan region. Egypt. J. Agronematol. 2: 111- 125.

Maareg, M. F.; M. A., Hassanein and A. M. Ebieda (1988a). Diseases of sugarbeet (Beta vulgaris L.) in Egypt. Con. Dev. Res., 22: 65- 73.

Maareg, M. F.; M. H. El- Deeb and A. M. Ebieda (1988b). Susceptibility of ten sugarbeet cultivars to root- knot nematodes, Meloidogyne spp. Alexandria Sci. Exch. 9 (3): 292- 302.

Maareg, M. F.; I. M. A., Gohar and A. M., Abdel Aal (2005). Susceptibility of twenty one sugarbeet varieties to root- knot nematodes, Meloidogyne incognita at West Nubariya district. J. Agric. Res., 83 (2): 789- 801.

Mc Ginnis, R. A. (1982). Beet sugar technology $3^{\text {rd }}$ ed. Dugarbeet development foundation Fort Collins $855 \mathrm{pp}$.

Oostenbrink, M. (1966). Major characteristics of the relation between nematodes and plants. Meloidogyne land bouwhogeschosl, Wageningen 66: 1- 46.

Sharma, S. B.; M. Mohiuddin; K. C. Jain and P. Ramananda (1994). Reaction of pigeonpea cultivars and germplasm accessions to the root- knot nematode, Meloidogyne javanica. J. Nematol. 26: 644- 652.

Yossef, M. M. A.; Wafaa, M. A. El- Nagdi and M. M. M., Abd Elgwad (2016). Categorization of certain imported sugarbeet varieties as affected by population density of root- knot nematode, Meloidogyne incognita in Egypt. Int. J. Chem. Tech. Res., 9 (7): 32- 36. 
تقييم بعض أصناف بنجر السكر لمدى قابليتها للإصابة بنيماتودا تعقد الجذور " Modified Host Parasite Index (MHPI) Scale

محمد فتحي معارج*، عبد المنعم الجندي***، منى السيد الثلبي***، عبير صلاح ياسين * ق قسم وقاية النباتات، معهد بحوث المحاصيل السكرية، مركز البحوث الزراعية، جيزة، مصر.

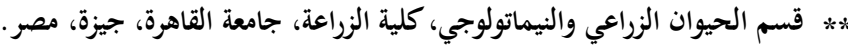

الملخص العبي

تم تقييم عشرة أصناف من بنجر السكر (خمسة أصناف وحيدة الأجنة وخمسة أصناف أخرى عديدة الأجنة) لمدى قابليتها للإصابة بنيماتودا تعقد الجذور "ميليدوحين إنكوجينيتا":

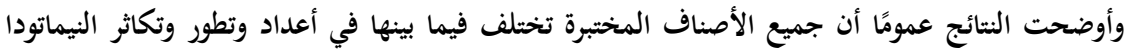

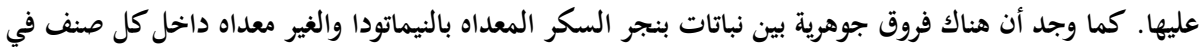

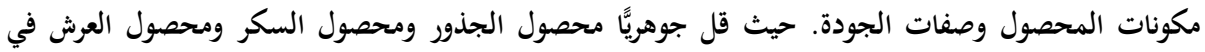
النباتات المصابة باستثناء الصنف "يونيفرس" لم يتأثر في محصول العرش والصنف "هيبا" لم يتأثر في محصولي مهصول العرش والسكر. كما وجد أن جميع صفات الجودة (نسبة السكروز ونسبة النقاوة ونسبة المواد الصلبة الذائبة الكلية) قلت

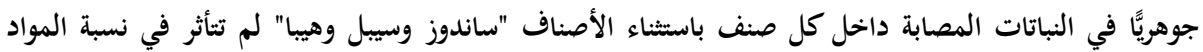

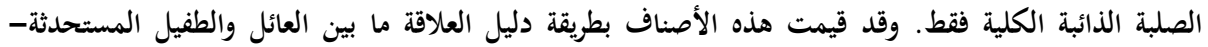
MHPI

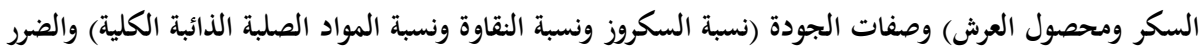
الناتج عن إصابة الجذور بالنيماتودا وتكاثرها عليها.

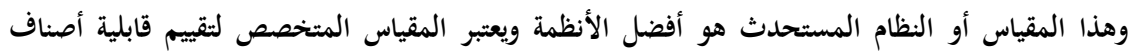

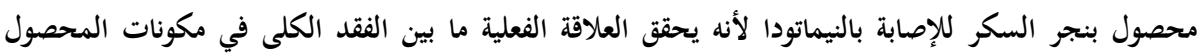

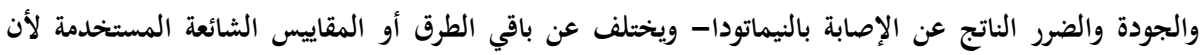

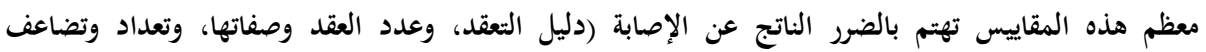

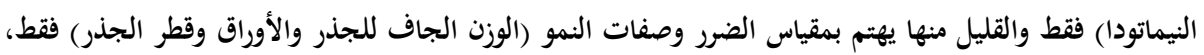

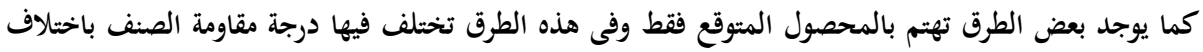
مجموعة الأصناف المختبرة الذي يقع فيها هذا الصنف. وجميع هذه الطرق تتجاهل الفقد الفعلي الناتج في مكونات

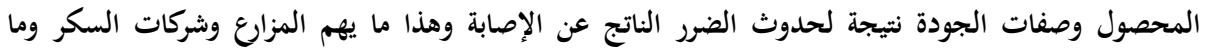
ينعكس على الدخل القومي. ونتيجة لتطبيق هذا المقياس أو النظام كمقياس خاص بتقييم أصناف بنجر السكر وجد أن الأصناف المختبرة

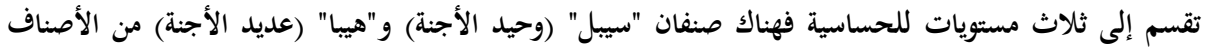

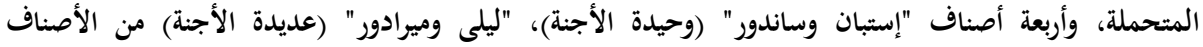

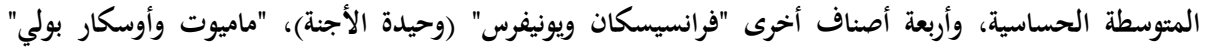


(عديدة الأجنة) من الأصناف المنخفضة الحساسية. ومن هذه النتائج يوصى بتسجيل "سيبل" و"هيبا" ضمن الأصناف الموصى بزراعتها في مصر في المناطق شديدة الإصابة. كما يوصى باستخدامها كعنصر من عناصر برامج المكافحة المتكاملة لنيماتودا تعقد الجذور. 